\title{
The Elemental Composition of Green Seaweed (Ulva rigida) Collected from Çanakkale, Turkey
}

\author{
Nermin Berik ${ }^{1}$, Ekrem Cem Çankırılıgil ${ }^{\star}$ (1)
}

Cite this article as: Berik, N., Cankiriligil, E. C. (2019). The elemental composition of Green Seaweed (Ulva rigida) collected from Çanakkale, Turkey. Aquatic Sciences and Engineering, 34(3), 74-79.

ORCID IDs of the authors: E.C.C.: 0000-0001-5898-4469; N.B.: 0000-0003-3015-8688

'Çanakkale Onsekiz Mart University, Faculty of Marine Sciences and Technology, Department of Fisheries and Processing Technology, Çanakkale, Turkey

${ }^{2}$ Central Fisheries Research Institute, Trabzon, Turkey

Submitted:

23.04.2019

Revision Requested

03.06.2019

Last Revision Received 22.06.2019

Accepted:

24.06.2019

Online published:

30.07.2019

Correspondence:

Ekrem Cem Çankırılıgil

E-mail:

ekremcem19@gmail.com

(C) Copyright 2019 by Aquatic Sciences and Engineering Available online at

https://dergipark.org.tr/ase

\begin{abstract}
Seaweeds or marine algae are rich in terms of minerals. They are used as food source due to the quality of their biological content in many countries. In this study, the elemental composition of green seaweed (Ulva rigida) was determined seasonally. Sampling was carried out seasonally from Turkey's Çanakkale strait and the collected algae were analyzed both wet and dried according to the Nordic Committee on Food Analysis (method 186). According to the results; calcium, potassium, magnesium, sodium were found as macro elements and boron, barium, chromium, copper, iron, manganese, zinc as micro elements and determined within the legal limits stated by food codex. However, neither cobalt nor nickel as trace metals were detected in all groups. Moreover, lead and cadmium (which are considered hazardous) were also not detected. While Mg was found to be the highest macro element in all seasons in wet algae, the highest macro mineral varied in dried algae is $\mathrm{Ca}$ in spring, $\mathrm{K}$ in summer and $\mathrm{Mg}$ in both autumn and winter. Fe was found to be the highest micro mineral followed by $\mathrm{B}, \mathrm{Zn}, \mathrm{Mn}$ and $\mathrm{Cu}$ both by season and by dried or wet ones $(P<0.05)$.
\end{abstract}

Keywords: Green seaweed, Ulva rigida, trace elements, Çanakkale strait, nutrient

\section{INTRODUCTION}

It is well known that the usage of macroalgae dates back many, many years. Native South Americans used to collect macroalgae in order to build food supplies and illness remedies (12000 years ago) (Ak, 2015; Dillehay et al., 2008). The utilization of algae takes part within the "Materia Medica" which belongs to ShenNung in B.C. 2700. However, algae products obtained by scientific methodologies are seen in last century (Sukatar, 2002). The use of Algae is particularly widespread in Southern Asia for nutrition, medicine and cosmetic industries, and fertilizer in agriculture (Atay, 1984; Kodalak, 2008). Sea lettuce is used as an additive for food and provender and is consumed in China, Japan, Korea, Indonesia, Malesia, France, United States, Canada and Scotland, freshly in salads and dried in soups, dishes and sauces
(Mchugh, 2003). Also, they are considered as biologically substantial nourishments (Fleurence, 1999; Rohani-Ghadikolaei, Abdulalian, \& Ng, 2012; Sánchez-Machado, López-Cervantes, López-Hernández, \& Paseiro-Losada, 2004) and it is significant following fish in aquatic products (Dawczynski, Schubert, \& Jahreis, 2007; Fleurence, 1999; Galland-Irmouli et al., 1999; Ortiz et al., 2006).

The Marine Strategy Framework Directive (MSFD) of the European Commission aims to deliver a good environmental status (GES) for the European marine environment by 2020. The eighth and ninth descriptor groups of this directive concern contaminants of fish and other seafood (Law et al., 2010; Swartenbroux et al., 2010). According to this directive, the toxic element compositions of the most commonly consumed fish and seafood species must be moni- 
tored in Mediterranean Sea. Therefore, the elemental composition of Ulva rigida is important in the usage of a food source. With that feature, Ulva rigida can also give an idea about the elemental pollution in the environment (Wan et al., 2017). Moreover, it can be used as an indicator species for lead (Haritonidis \& Malea, 1999; Malea \& Haritonidis, 2000) and aluminum (Favero, Cattalini, Bertaggia, \& Albergoni, 1996). In this study, the elemental composition of Ulva rigida were evaluated considering MSFD instructions to highlight Ulva rigida as a valuable food source and provide information for further studies in the future.

\section{MATERIAL AND METHODS}

\section{Material}

In this research, green seaweed (Ulva rigida) was used. Ulva rigida, also known as sea lettuce, is a cosmopolite species and distributed along the Turkish coasts especially in shallow and rocky bottoms which are rich in nutrients such as nitrogen and phosphorus (Cirik, 2001; Cirik \& Cirik, 1999). This algae's tallus size varied from 1-2 cm up to $30 \mathrm{~cm}$ and clings to the substrate with a short stem (Irkin, 2009). The green seaweed is shown in Figure 1.

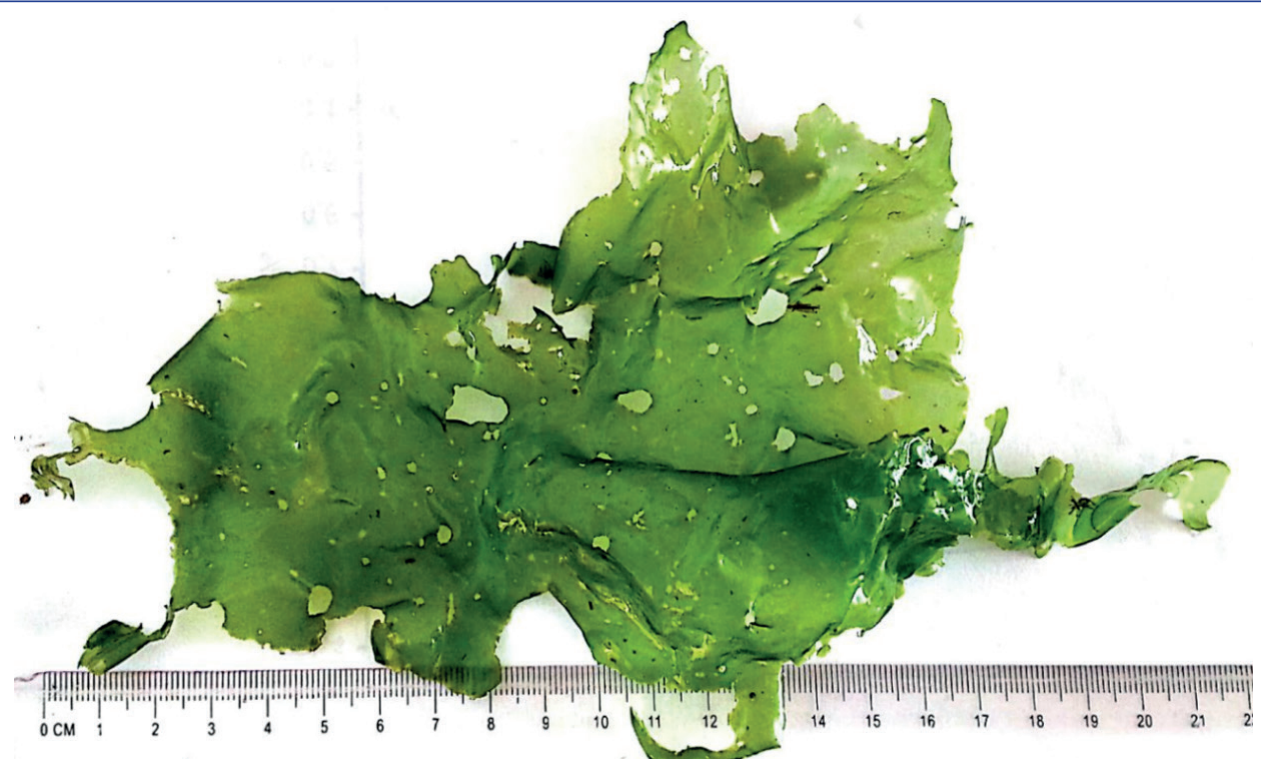

Figure 1. Green seaweed (Ulva rigida) collected from Çanakkale, Turkey.

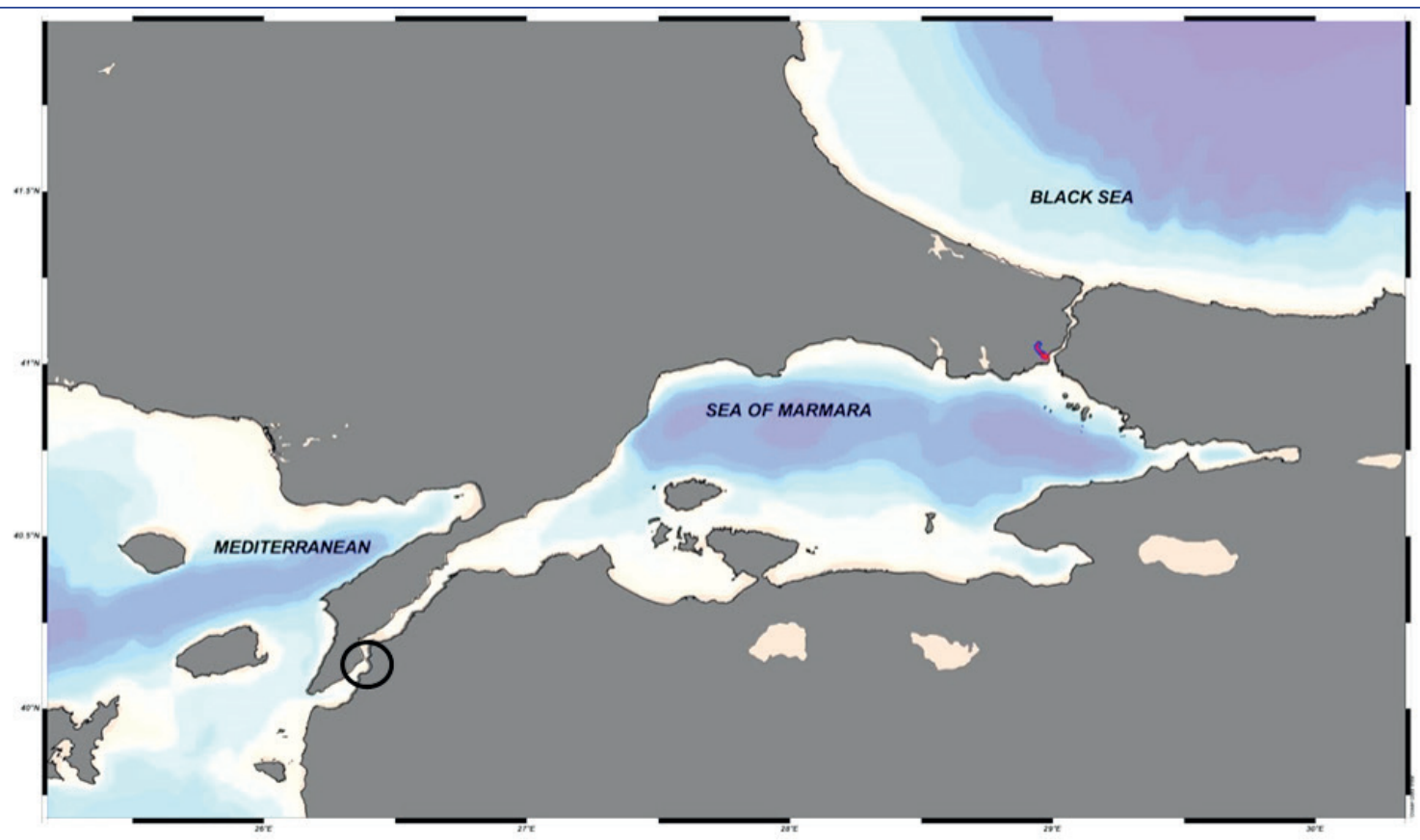

Figure 2. Sampling area in Çanakkale, Turkey. The map was created with Ocean Data View (ODV) Software (4006'08.6" N, $\left.26^{\circ} 23^{\prime} 13.7^{\prime \prime} \mathrm{E}\right)$. 


\section{Sampling}

Green seaweed samples weighing approximately $2 \mathrm{~kg}$ were collected from Kepez station in the Çanakkale strait in the Northern Aegean Sea, Turkey. Sampling was carried out seasonally/quarterly between February/2011 and February/2012. The sampling station of green seaweed (Ulva rigida) is shown in Figure 2 and the map used was created with Ocean Data View (ODV) software (Schlitzer, 2019). Samples were stored in 5-liter bottles of sea water taken from the sampling station and transferred to the laboratories in the Faculty of Marine Sciences and Technology in Çanakkale Onsekiz Mart University. Subsequently, the samples were cleaned of any unwanted substances that seaweed carries such as sand particles, epiphyte plants and other aquatic organisms. The sand removal process was carried out by scrubbing with a soft brush in salty water with $0.3 \%$ salinity. After this step, the green seaweed samples were separated into two groups. The element analysis was performed on the first group immediately. The second group was dried at $40{ }^{\circ} \mathrm{C}$ for 48 hours in a drying oven (Shin Saeng/ SDON-302 model). Finally, the dried samples were then analyzed.

\section{Element Analysis}

The element analyses were carried out according to the Nordic Committee on Food Analysis (method 18) (NMKL, 2007) with three parallel and three replicates. These algae are consumed both wet and dried and since some elements can be lost during the drying process, the analyses were carried out with both wet and dried samples. The VH6 Lab Single Element Atomic Absorbsion CRM standards were used in the analyses. Furthermore, the regulations recommended by the MSFD were applied to avoid secondary contamination in the sample preparations. In analysis, $0.5 \mathrm{mg}$ of the samples were weighed using politetrafloroetilen plates (for microwave use) and they were digested with a 10 milliliter concentrated nitric acid $\left(\mathrm{HNO}_{3}\right)$ via Speedwave Berghof model microwave at $160{ }^{\circ} \mathrm{C}$ in gradually increasing heat conditions. After the samples were completely burned and had become clear mixtures, they were filtered and diluted with distilled water. In the burning process sequence, the mixtures were analyzed with the ICP-AES (Varian Liberty AX Sequential ICP-AES) in Çanakkale Onsekiz Mart University's Main Laboratory. The elements aluminum (Al), boron (B), barium (Ba), calcium (Ca), cadmium (Cd), cobalt (Co), chromium (Cr), copper (Cu), iron (Fe), potassium $(\mathrm{K})$, magnesium $(\mathrm{Mg})$, manganese $(\mathrm{Mn})$, sodium $(\mathrm{Na})$, nickel $(\mathrm{Ni})$, lead $(\mathrm{Pb})$ and zinc $(\mathrm{Zn})$ were analyzed. Finally, the data was analyzed and expressed as mg/g for macro elements and $\mu \mathrm{g} / \mathrm{g}$ for micro elements on a wet matter basis.

\section{RESULTS AND DISCUSSION}

According to the results, four macro elements (calcium, potassium, magnesium, sodium), and seven micro elements (aluminum, boron, barium, chromium, copper, iron, manganese and zinc), were detected. The macro elements were expressed as mg/g and micro elements as $\mu \mathrm{g} / \mathrm{g}$. While magnesium was detected as the most abundant macro element in wet samples in autumn, it was detected as least abundant in summer $(P<0.05)$. The statistical differences were determined between elements seasonally $(P<0.05)$. The elemental composition of dried the seaweeds were

Table 1. Elemental composition of wet green seaweed (Ulva rigida)

\begin{tabular}{|c|c|c|c|c|}
\hline \multirow{2}{*}{ Elements } & \multicolumn{4}{|c|}{ Seasons } \\
\hline & Winter & Spring & Summer & Autumn \\
\hline \multicolumn{5}{|c|}{ Macro elements $(\mathrm{mg} / \mathrm{g})$} \\
\hline $\mathrm{Ca}$ & $0.69 \pm 0.00^{c}$ & $3.23 \pm 0.30^{a}$ & $0.46 \pm 0.02^{c}$ & $1.11 \pm 0.07^{b}$ \\
\hline K & $5.66 \pm 0.03^{c}$ & $6.09 \pm 0.03^{b}$ & $4.68 \pm 0.12^{d}$ & $7.18 \pm 0.11^{\mathrm{a}}$ \\
\hline $\mathrm{Mg}$ & $5.97 \pm 0.06^{c}$ & $8.41 \pm 0.03^{b}$ & $5.69 \pm 0.08^{d}$ & $8.92 \pm 0.09^{a}$ \\
\hline $\mathrm{Na}$ & $5.19 \pm 0.04 a^{b}$ & $5.74 \pm 0.24^{a}$ & $4.44 \pm 0.46^{b}$ & $4.62 \pm 0.40^{b}$ \\
\hline \multicolumn{5}{|c|}{ Micro elements $(\mu \mathrm{g} / \mathrm{g})$} \\
\hline $\mathrm{Al}$ & $89.00 \pm 2.27^{b}$ & $60.00 \pm 0.72^{c}$ & $44.93 \pm 0.46^{d}$ & $110.80 \pm 0.20^{a}$ \\
\hline$B$ & $17.67 \pm 0.61^{c}$ & $15.53 \pm 0.31^{d}$ & $52.27 \pm 0.46^{a}$ & $33.53 \pm 0.61^{b}$ \\
\hline $\mathrm{Ba}$ & $0.53 \pm 0.06^{b}$ & $0.80 \pm 0.00^{a}$ & $0.67 \pm 0.12^{\mathrm{ab}}$ & $0.80 \pm 0.00^{a}$ \\
\hline Co & $<0.035$ & $<0.035$ & $<0.035$ & $<0.035$ \\
\hline $\mathrm{Cr}$ & $<0.010$ & $0.20 \pm 0.00^{c}$ & $0.60 \pm 0.00^{a}$ & $0.20 \pm 0.00^{b}$ \\
\hline $\mathrm{Cu}$ & $3.27 \pm 0.76^{a}$ & $3.00 \pm 0.72^{\mathrm{ab}}$ & $2.00 \pm 0.69^{a b}$ & $1.33 \pm 0.64^{b}$ \\
\hline $\mathrm{Fe}$ & $227.87 \pm 3.41^{\mathrm{a}}$ & $188.20 \pm 6.54^{b}$ & $124.60 \pm 0.87^{c}$ & $225.07 \pm 1.27^{\mathrm{a}}$ \\
\hline $\mathrm{Mn}$ & $3.00 \pm 0.00^{c}$ & $3.07 \pm 0.12^{c}$ & $4.60 \pm 0.00^{b}$ & $5.40 \pm 0.53^{a}$ \\
\hline $\mathrm{Ni}$ & $<0.035$ & $<0.035$ & $<0.035$ & $<0.035$ \\
\hline $\mathrm{Zn}$ & $13.20 \pm 0.20^{a}$ & $8.47 \pm 0.12^{b}$ & $2.00 \pm 0.00^{d}$ & $4.40 \pm 0.00^{c}$ \\
\hline \multicolumn{5}{|c|}{ Toxic elements $(\mu \mathrm{g} / \mathrm{g})$} \\
\hline $\mathrm{Cd}$ & $<0.035$ & $<0.035$ & $<0.035$ & $<0.035$ \\
\hline $\mathrm{Pb}$ & $<0.035$ & $<0.035$ & $<0.035$ & $<0.035$ \\
\hline
\end{tabular}


found to be similar to the wet ones. However, a relative increase was detected in both macro and trace element concentrations of dried samples due to the extraction of water from the samples during the drying process. The macro element composition of Ulva rigida is shown in Table 1.

Macro and micro elements accumulate in macroalgae with greater concentrations than the surrounding waters (Bonanno \& Orlando-Bonaca, 2018). Iron was found as the most abundant trace element in both wet samples (with the amount of $227.87 \mu \mathrm{g} / \mathrm{g}$ in winter), and dried samples (with the amount of $574.53 \mu \mathrm{g} / \mathrm{g}$ in summer). A noticeable amount of $\mathrm{Fe}, \mathrm{Al}$ and $\mathrm{B}$ were also found in the samples. The Mediterranean Sea is rich in terms of dissolved iron and aluminum (Chou \& Wollast, 1997; Guieu et al., 2002) and these elements are usually accumulated in Ulva rigida (Favero, Cattalini, Bertaggia, \& Albergoni, 1996; Malea \& Haritonidis, 2000). Boron, which is found in high concentrations in sea water (Demey et al., 2014; Foster, Strandmann Pogge von, \& Rae, 2010), is a mineral that has recently generated benefits for human health (Meacham, Karakas, Wallace, \& Altun, 2010; Nielsen, 1997; Nielsen \& Meacham, 2016) and it was found in all samples of our study. Also; zinc, manganese, copper and a small amount of chromium and barium were detected in Ulva rigida. Only chromium wasn't detected in winter. Chromium, which was detected as $0.20 \mu \mathrm{g} / \mathrm{g}$ in wet samples in fall, wasn't found in dried samples due to the dehumidification.

Two trace elements, cobalt and nickel were not detected in any samples during the whole year. Mediterranean waters are not rich in terms of nickel and cobalt (Achterberg \& Van Den Berg, 1997; Swanner et al., 2014). However, according to other research using similar methods, these two elements were detected, albeit in small quantities) in other marine organisms caught from the Mediterranean Sea (Berik, Çankırılıgil, \& Gül, 2017; Joksimovic, Tomic, Stankovic, Jovic, \& Stankovic, 2011; Mutlu, Türkmen, Türkmen, Tepe, \& Ateş, 2012; Türkmen, Türkmen, Tepe, \& Çekiç, 2010). Consequently, we might suggest that the cobalt and nickel accumulate less in Ulva rigida compared to other elements. According to our analyses, cadmium and lead - among the most dangerous toxic elements - were not detected in green seaweed. Several studies showed that, Ulva rigida accumulates these toxic metals, especially lead, in significant amounts. (Haritonidis \& Malea, 1999; Saeed \& Moustafa, 2013; Ustunada, Erdugan, Yilmaz, Akgul, \& Aysel, 2011). This research also showed that, the sampling station of Ulva rigida was more reliable in terms of lead and cadmium pollution having regard to these low values. The micro element composition of Ulva rigida is shown in Table 2.

As regards the elemental studies on sea lettuces in the Çanakkale Province, these are generally focused on iron (Fe) cadmium (Cd) lead (Pb) zinc ( $\mathrm{Zn}$ ) and copper (Cu) (Ozden \& Tuncer, 2015; Ustunada, Erdugan, Yilmaz, Akgul, \& Aysel, 2011). As for the present study, we can only compare the results with the previous studies in the Çanakkale Province, in terms of $\mathrm{Cu}, \mathrm{Fe}$ and $\mathrm{Zn}$. Ustunada, Erdugan, Yilmaz, Akgul, \& Aysel (2011) studied the seasonal alterations in the content of $\mathrm{Cd}, \mathrm{Zn}, \mathrm{Pb}$ and $\mathrm{Cu}$ in Ulva

Table 2. Elemental composition of dried green seaweed (Ulva rigida)

\begin{tabular}{|c|c|c|c|c|}
\hline \multirow{2}{*}{ Elements } & \multicolumn{4}{|c|}{ Seasons } \\
\hline & Winter & Spring & Summer & Autumn \\
\hline \multicolumn{5}{|c|}{ Macro elements $(\mathrm{mg} / \mathrm{g})$} \\
\hline $\mathrm{Ca}$ & $2.11 \pm 0.07^{b}$ & $12.73 \pm 0.08^{a}$ & $1.56 \pm 0.02^{c}$ & $2.23 \pm 0.03^{b}$ \\
\hline K & $7.01 \pm 0.01^{c}$ & $7.19 \pm 0.02^{b}$ & $6.52 \pm 0.08^{d}$ & $8.17 \pm 0.01^{a}$ \\
\hline $\mathrm{Mg}$ & $10.55 \pm 0.06^{a}$ & $8.91 \pm 0.04^{c}$ & $6.13 \pm 0.08^{d}$ & $10.22 \pm 0.03^{b}$ \\
\hline $\mathrm{Na}$ & $6.27 \pm 0.27^{a}$ & $6.31 \pm 0.13^{a}$ & $5.83 \pm 0.41^{\mathrm{ab}}$ & $5.21 \pm 0.41^{b}$ \\
\hline \multicolumn{5}{|c|}{ Micro elements $(\mu \mathrm{g} / \mathrm{g})$} \\
\hline $\mathrm{Al}$ & $158.00 \pm 3.80^{c}$ & $211.87 \pm 2.66^{a}$ & $171.73 \pm 6.01^{b}$ & $224.60 \pm 6.10^{a}$ \\
\hline B & $36.87 \pm 0.42^{c}$ & $34.73 \pm 0.12^{d}$ & $59.40 \pm 0.69^{a}$ & $45.93 \pm 1.21^{b}$ \\
\hline $\mathrm{Ba}$ & $0.60 \pm 0.00^{d}$ & $1.27 \pm 0.12^{b}$ & $0.87 \pm 0.12^{c}$ & $1.67 \pm 0.12^{\mathrm{a}}$ \\
\hline Co & $<0.035$ & $<0.035$ & $<0.035$ & $<0.035$ \\
\hline $\mathrm{Cr}$ & $<0.010$ & $0.20 \pm 0.00^{a}$ & $0.07 \pm 0.12^{\mathrm{ab}}$ & $<0.010$ \\
\hline $\mathrm{Cu}$ & $6.33 \pm 0.64^{a}$ & $4.13 \pm 0.64^{b}$ & $1.00 \pm 0.53^{c}$ & $1.93 \pm 0.46^{c}$ \\
\hline $\mathrm{Fe}$ & $293.93 \pm 4.12^{d}$ & $461.47 \pm 8.03^{b}$ & $574.53 \pm 5.60^{a}$ & $399.87 \pm 7.91^{c}$ \\
\hline $\mathrm{Mn}$ & $5.47 \pm 1.50^{b}$ & $10.07 \pm 0.12^{b}$ & $10.27 \pm 0.12^{\mathrm{a}}$ & $6.93 \pm 0.12^{b}$ \\
\hline $\mathrm{Ni}$ & $<0.035$ & $<0.035$ & $<0.035$ & $<0.035$ \\
\hline $\mathrm{Zn}$ & $20.13 \pm 0.12^{\mathrm{a}}$ & $17.60 \pm 0.20^{b}$ & $13.80 \pm 0.00^{d}$ & $14.40 \pm 0.20^{c}$ \\
\hline \multicolumn{5}{|c|}{ Toxic elements $(\mu \mathrm{g} / \mathrm{g})$} \\
\hline $\mathrm{Cd}$ & $<0.035$ & $<0.035$ & $<0.035$ & $<0.035$ \\
\hline $\mathrm{Pb}$ & $<0.035$ & $<0.035$ & $<0.035$ & $<0.035$ \\
\hline
\end{tabular}


rigida samples, in six different locations of the Dardanelles (Çanakkale), and did not detect any of the elements in levels greater than $1 \mathrm{\mu g} / \mathrm{g}$ within any of the dry algae samples collected. However, Ozden and Tuncer (2015) did not detect the elements of $\mathrm{Pb}$ and $\mathrm{Cu}$ in levels above $1 \mu \mathrm{g} / \mathrm{g}$ in the dry samples of Ulva rigida collected seasonally from five different locations in the Dardanelles. They also reported that the seasonal average amounts of $\mathrm{Zn}$ and Fe were between 1.01-6.5 $\mu \mathrm{g} / \mathrm{g}$ and 2.25$10.87 \mu \mathrm{g} / \mathrm{g}$, respectively. The results of the element quantities in the present study were observed to be higher compared to the abovementioned studies, for example, Cu was between 1.00 and $6.33 \mu \mathrm{g} / \mathrm{g} ; \mathrm{Fe}, 294-575 \mu \mathrm{g} / \mathrm{g}$; and $\mathrm{Zn}, 13.80-20.13 \mu \mathrm{g} / \mathrm{g}$. It is generally considered that the differences in the results between this study and other studies stems from the sampling years and a dissimilarity in sampling locations. The Dardanelles, being a specific current system can contain different proportions of minerals during various years and stations due to taking nutrition particularly from the water bodies originating from the Black Sea. Furthermore, the magnitude of the algae is a distinctive feature in terms of mineral composition. Older algae have better ability of absorbing minerals from sea water.

According to legislation, the acceptable daily limits of copper is $0.5 \mathrm{mg} / \mathrm{kg}$, and manganese is between $0.4-1.0 \mathrm{mg} / \mathrm{kg}$ of bodyweight (Codex Alimentarius, 2007; 2011). There are no legal limits for aluminum and barium in meat products but the EFSA (2013) stated that aluminum exposure should not exceed $1 \mathrm{mg} /$ $\mathrm{kg}$ weekly for humans and the Codex Alimentarius Committee (1996) stated that the acceptable barium limit is $1 \mathrm{mg} / \mathrm{l}$ in drinking water. Nickel and chromium were found very low - just slightly higher than the detection limits. Additionally, certain beneficial elements, such as boron and zinc, should be present in foods in the amounts of $0.5-0.4 \mathrm{mg} / \mathrm{kg}$ and $15 \mathrm{mg} / \mathrm{kg}$ of body weight, respectively (Codex Alimentarius, 2007; Jopp, 2012; WHO, 2013).

\section{CONCLUSION}

In this research, the elemental composition of green seaweed (Ulva rigida) and level of food safety was evaluated. In sum, Ulva rigida is rich in terms of certain beneficial micro elements such as iron, boron and zinc - and within acceptable values. Furthermore, the elements lead and cadmium (considered as hazardous), were not detected. With these features and the supporting studies related to nutrient content for this species, Ulva rigida we can suggest that the seafood sector is a convenient and secure food source if it is collected from not-polluted and safe areas.

Acknowledgements: This research was presented under the same title in "ISEEP-2017 VIII. The International Symposium on Ecology and Environmental Problems" October 4th -7th 2017. It is part of a project known as "The Determination of Seasonal Chemical Composition of Sea Lettuce (Ulva rigida) and Utilization as a Human Food" and is supported by the Çanakkale Onsekiz Mart University Scientific Research Projects Coordination Unit, Turkey (2012/023).

Conflict of Interest: Authors state that there is no conflict of interests.

\section{REFERENCES}

Achterberg, E. P., \& Van Den Berg, C. M. G. (1997). Chemical speciation of chromium and nickel in the western Mediterranean. Deep Sea Research Part II: Topical Studies in Oceanography, 44(3-4), 693-720. [CrossRef]

Ak, i. (2015). Sucul ortamın ekonomik bitkileri; makro algler (in Turkish). Dünya Gıda Dergisi, 12, 88-97.

Andreas Jopp, (2012). Vitamins. Life's hidden miracle, Cologne, Germany. Atay, D. (1984). Bitkisel Su Ürünleri Üretim Tekniği (in Turkish). AnkaraTürkiye: Ankara University Agriculture Faculty Publishing.

Berik, N., Çankırılıgil, E. C., \& Gül, G. (2017). Mineral content of smooth scallop (Flexopecten glaber) caught Canakkale, Turkey and evaluation in terms of food safety. Journal of Trace Elements in Medicine and Biology, 42, 97-102. [CrossRef]

Bonanno, G., \& Orlando-Bonaca, M. (2018). Chemical elements in Mediterranean macroalgae. A review. Ecotoxicology and Environmental Safety, 148, 44-71. [CrossRef]

Chou, L., \& Wollast, R. (1997). Biogeochemical behavior and mass balance of dissolved aluminum in the western Mediterranean Sea. Deep-Sea Research Part II: Topical Studies in Oceanography, 44(3-4), 741-768. [CrossRef]

Cirik, Ş. (2001). Gökova Körfezi Deniz Bitkileri (in Turkish). Izmir-Türkiye: D.E.U. Marine Science and Technology Institute, Piri Reis Publishing.

Cirik, S.., \& Cirik, S. (1999). Su Bitkileri (in turkish). Izmır-Turkey: Ege University Publisher, Fisheries Faculty.

Codex Alimentarius Commision (1996), Report of the fifth session of the Codex committee on natural mineral waters, Thun, Switzerland.

Codex Alimentarius Commision (2007), Matters arising from the reports of the commission, codex committees and task forces, FAO Headquarters, Rome, Italy. ftp://ftp.fao.org/codex/Meetings/CAC/ cac30/al3009De.pdf

Codex Alimentarius Commision (2011), Joint fao/who food standards programme codex, committee on contaminants in foods fifth session, the hague, the netherlands.

Dawczynski, C., Schubert, R., \& Jahreis, G. (2007). Amino acids, fatty acids, and dietary fibre in edible seaweed products. Food Chemistry, 103, 891-899. [CrossRef]

Demey, H., Vincent, T., Ruiz, M., Nogueras, M., Sastre, A. M., \& Guibal, E. (2014). Boron recovery from seawater with a new low-cost adsorbent material. Chemical Engineering Journal, 254, 463-471. [CrossRef]

Dillehay, T. D., Ramírez, C., Pino, M., Collins, M. B., Rossen, J., \& PinoNavarro, J. D. (2008). Monte Verde: Seaweed, food, medicine, and the peopling of South America. Science, 320, 784-786. [CrossRef]

European Food Safety Authority, EFSA (2013), Dietary exposure to aluminium-containing food additives, Parma, Italy. doi:http://www. efsa.europa.eu/sites/default/files/scientific_output/files/main_ documents/411e.pdf.

Favero, N., Cattalini, F., Bertaggia, D., \& Albergoni, V. (1996). Metal accumulation in a biological indicator (Ulva rigida) from lagoon of Venice (Italy). Archives of Environmental Contamination and Toxicology, 31(1), 9-18. [CrossRef]

Fleurence, J. (1999). Seaweed proteins: Biochemical, nutritional aspects and potential uses. Trends in Food Science and Technology, 10, 2528. [CrossRef]

Foster, G. L., Strandmann Pogge von, P. A. E., \& Rae, J. W. B. (2010) Boron and magnesium isotopic composition of seawater. Geochemistry, Geophysics, Geosystems, 11(8), 1-10. [CrossRef]

Galland-Irmouli, A. V., Fleurence, J., Lamghari, R., Lucon, M., Rouxel, C., Barbaroux, O., Bronowicki, J. P., Villaume, C., \& Gueant, J. L. (1999). Nutritional value of proteins from edible seaweed Palmaria palmata (Dulse). Journal of Nutritional Biochemistry, 10, 353-359. [CrossRef] 
Guieu, C., Bozec, Y., Blain, S., Ridame, C., Sarthou, G., \& Leblond, N. (2002). Impact of high Saharan dust inputs on dissolved iron concentrations in the Mediterranean Sea. Geophysical Research Letters, 29(19), 17-1-17-4. [CrossRef]

Haritonidis, S., \& Malea, P. (1999). Bioaccumulation of metals by the green alga Ulva rigida from Thermaikos Gulf, Greece. Environmental Pollution, 104(3), 365-372. [CrossRef]

Irkin, L. C. (2009). Çanakkale Boğazında yayılış gösteren bazı makro alglerin kimyasal kompozisyonunun araştırılması (In turkish). Institute of Applied Sciences.

Joksimovic, D., Tomic, I., Stankovic, A. R., Jovic, M., \& Stankovic, S. (2011), Trace metal concentrations in Mediterranean blue mussel and surface sediments and evaluation of the mussels quality and possible risks of high human consumption. Food Chemistry, 127(2), 632-637. [CrossRef]

Kodalak, N. (2008). Sinop Kıyılarındaki "Cystoseira barbata" deniz yosunundan aljinat üretimi üzerine bir araştırma (in Turkish). Fen Bilimleri Enstitüsü.

Law, R., Hanke, G., Angelidis, M., Batty, J., Bignert, A., Dachs, J., Davies, I., Denga, Y., Duffek, A., Herut, B., Hylland, K., Lepom, P., Leonards, P., Mehtonen, J., Piha, H., Roose, P., Tronczynski, J., Velikova, V., \& Vethaak, D. (2010). Marine Strategy Framework Directive, Contaminants and Pollution Effects. Luxembourg.

Malea, P., \& Haritonidis, S. (2000). Use of the green alga Ulva rigida C. Agardh as an indicator species to reassess metal pollution in the Thermaikos Gulf, Greece, after 13 years. Journal of Applied Phycology, 12(2),169-176.

Mchugh, D. J. (2003). A guide to the seaweed industry. Rome-Italy.

Meacham, S., Karakas, S., Wallace, A., \& Altun, F. (2010). Boron in human health: Evidence for dietary recommendations and public policies, 36-53. [CrossRef]

Mutlu, C., Türkmen, A., Türkmen, M., Tepe, Y., \& Ateş, A. (2012). Comparison of the heavy metal concentrations in Atlantic horse mackerel, Trachurus trachurus, from coastal waters of Turkey. Fresenius Environmental Bulletin, 21(2), 304-307.

Nielsen, F. H. (1997). Boron in human and animal nutrition. Plant and Soil, 193(13), 199-208. [CrossRef]

Nielsen, F. H., \& Meacham, S. L. (2016). Growing evidence for human health benefits of boron, 16(3), 169-180. [CrossRef]

NMKL. (2007). Nordic Committee on Food Analysis, Method No:186.

Ortiz, J., Romero, N., Robert, P., Araya, J., Lopez-Hernandez, J., Bozzo, C., Navarrete, E., Osorio, A., \& Rios, A. (2006). Dietary fiber, amino acid, fatty acid and tocopherol contents of the edible seaweeds Ulva lactuca and Durvillaea antarctica. Food Chemistry, 99, 98-104. [CrossRef]
Ozden, S., \& Tuncer, S. (2015). Heavy metal concentrations (Pb, Cu, Zn and Fe) in Ulva rigida (Dardanelles, Çanakkale). Bitlis Eren Üniversitesi Fen Bilimleri Dergisi, 4, 34-42. [CrossRef]

Rohani-Ghadikolaei, K., Abdulalian, E., \& Ng, W. K. (2012). Evaluation of the proximate, fatty acid and mineral composition of representative green, brown and red seaweeds from the Persian Gulf of Iran as potential food and feed resources. Journal of Food Science and Technology-Mysore, 49, 774-780. [CrossRef]

Saeed, S. M., \& Moustafa, Y. T. A. (2013). The seaweed (Green Macroalgae), Ulva sp. as bioindicator of metal pollution in the Mediterranean coast, Alexandria region, Egypt. Egyptian Journal of Aquatic Biology and Fisheries, 17(3), 57-68. [CrossRef]

Sánchez-Machado, D.I., López-Cervantes, J., López-Hernández, J., \& Paseiro-Losada, P. (2004). Fatty acids, total lipid, protein and ash contents of processed edible seaweeds. Food Chemistry, 85, 439444. [CrossRef]

Schlitzer, R. (2019). Ocean Data View. http://odv.awi.de.

Sukatar, A. (2002). Alg Kültür Yöntemleri (in Turkish). Bornova-izzmir: Ege Üniversitesi Basımevi.

Swanner, E. D., Planavsky, N. J., Lalonde, S. V., Robbins, L. J., Bekker, A., Rouxel, O. J., Saito, M.A., Kappler, A., Mojzsis, S.J., \& Konhauser, K. O. (2014). Cobalt and marine redox evolution. Earth and Planetary Science Letters, 390, 253-263. [CrossRef]

Swartenbroux, F., Albajedo, B., Angelidis, M., Aulne, M., Bartkevics, V., Besada, V., Bignert, A., Bitterhof, A., Hallikainen, A., Hoogenboom, R., Jorhem, L., Jud, M., Law, R., Cederberg, D.L., McGovern, E., Miniero, R., Schneider, R., Velikova, V., Verstraete, F., Vinas, L., \& Vlad, S. (2010). Marine Strategy Framework Directive, Contaminants in Fish and Other Seafood. Luxembourg.

Türkmen, A., Türkmen, M., Tepe, Y., \& Çekiç, M. (2010). Metals in tissues of fish from Yelkoma Lagoon, northeastern Mediterranean. Environmental Monitoring and Assessment, 168(1-4), 223-230. [CrossRef]

Ustunada, M., Erdugan, H., Yilmaz, S., Akgul, R., \& Aysel, V. (2011). Seasonal concentrations of some heavy metals $(\mathrm{Cd}, \mathrm{Pb}, \mathrm{Zn}$, and $\mathrm{Cu})$ in Ulva rigida J. Agardh (Chlorophyta) from Dardanelles (Canakkale, Turkey). Environmental Monitoring and Assessment, 177(1-4), 337342. [CrossRef]

Wan, A., Wilkes, R., Heesch, S., Bermejo, R., Johnson, M., Morrison, L., \& Kalka, G. (2017). What can sea lettuce tell us about coastal pollution?, Environmental Science Journal for Teens, 1-5.

World Health Organization, WHO (1998). Environmental Health Criteria 204, Boron, Geneva. http://www.inchem.org/documents/ehc/ehc/ ehc204.htm 